\title{
Efficacy of the anti-VZV (anti-HSV3) vaccine in HSVI and HSV2 recurrent herpes simplex disease: a prospective study
}

This article was published in the following Dove Press journal:

Open Access Journal of Clinical Trials

27 July 2012

Number of times this article has been viewed

\author{
Jacqueline Le Goaster' \\ Sylvie Gonzalo² \\ Patrice Bourée' \\ Frederic Tangy ${ }^{3}$ \\ Anne-Lise Haenni ${ }^{4}$ \\ 'Department of Tropical Diseases, \\ Centre Hospitalo-Universitaire \\ (CHU), University of Paris XI, Le \\ Kremlin Bicêtre, ${ }^{2}$ Biomnis Laboratory, \\ Ivry-sur-Seine, ${ }^{3}$ Retro-Virology, Centre \\ National de Recherche Scientifique \\ (CNRS), Pasteur Institute, Paris; \\ ${ }^{4}$ Jacques Monod Institute, Centre \\ National de Recherche Scientifique \\ (CNRS), University of Paris VII, Paris, \\ France
}

Background: The aim of this study was to evaluate the possibility of using the anti-varicella zoster virus (anti-VZV, also known as anti-HSV3) vaccine against orobuccal herpes simplex virus type 1 (HSV1) and genital herpes simplex virus type 2 (HSV2). This was suggested by study of the phylogenetic tree of members of the herpes virus family, which showed a close relationship between VZV (HSV3) and the HSV1 and HSV2 herpes viruses.

Methods: The present prospective study was conducted from January 2005 through January 2011. Twenty-four patients afflicted with HSV1 and HSV2 herpes recurrences over a period of years, numbering 6-8 and more recurrences per year, agreed to receive the anti-VZV vaccine. They were compared with 26 nonvaccinated patients presenting with herpes simplex diseases 2-5 times a year. All 50 patients were documented with anti-HSV1, anti-HSV2, and anti-VZV antibody serological testing.

Results: From 2005 through 2011, for the 24 anti-VZV vaccinated patients, the average number of herpes relapses decreased to 0 , correlated with an increased anti-VZV antibody level and clinical recovery of all patients, whereas no improvement was observed for the 26 nonvaccinated herpes patients.

Conclusion: Data for the anti-VZV serological antibody levels tested before and after antiVZV vaccination showed a significant $(P<0.001)$ increase among vaccinated patients. This suggests defective anti-VZV immune power in these patients. After 6 years of positive results for anti-VZV vaccine, this is a logical and fair hypothesis. We can now undertake a randomized study to confirm these findings.

Keywords: HSV1/HSV2 herpes prevention, anti-VZV (HSV3) vaccine, anti-VZV vaccine therapy

\section{Introduction}

The human HSV1 and HSV2 herpes simplex viruses and varicella zoster virus (VZV, also known as HSV3) are members of the subfamily Alphaherpesvirinae of the Herpesviridae family, ${ }^{1}$ that were incorporated in 2009 into the new order Herpesvirales. As McGeoch et $\mathrm{al}^{3}$ wrote, "morphologically herpes viruses are distinct from all other viruses". These viruses contain a large dsDNA genome, and are found in a large and varied number of hosts, including mammals, birds, reptiles, fishes, frogs, and oysters. They are characterized by a very brief lytic cycle, ${ }^{3}$ and latency in epithelial cells, the sensory ganglia, and neurons. ${ }^{4}$ Infections caused by HSV are nearly exclusively the result of local or regional spread by cell-to-cell transmission, involving cell-mediated immunity. HSV1, HSV2, and VZV possess related genetic expressions but with distinct recurrence frequencies. ${ }^{5}$ This close genetic relationship led us to take a new clinical
Correspondence: Jacqueline Le Goaster Medical office, 2 rue Jean Richepin,

75116 , Paris, France

$\mathrm{Tel}+33$ I 4503 II 35

Fax +3395326 7560

Email j.lego@free.fr 
approach to the treatment of recurrent herpes simplex disease based on fundamental phylogenetic herpes virus analysis ${ }^{1,2}$ (Figure 1).

The hypothesis of cross-reactivity based on the immunological power of the three herpes viruses (HSV1, HSV2, HSV3) was first proposed in studies in 1969 by Schmidt et al. ${ }^{6}$ A study by Sadaoka et $\mathrm{al}^{7}$ pointed to measurement of VZVspecific cell-mediated immunity. These two scientific teams, and many others, led the way to this prospective study.

In 2005, we observed two otherwise healthy teenagers suffering from relapses of orobuccal herpes disease following repeated varicella infection (chickenpox) beyond childhood. Their relapses were resistant to continuous prophylaxis, such as Zovirax ${ }^{\circledR}$ (or its generic acyclovir) or Zelitrex ${ }^{\circledR}$ (or its generic valacyclovir), administered discontinuously in low doses for several years. These clinical observations of repeated chickenpox during childhood followed by herpes disease for months or years suggested a possible relationship with an initial anti-VZV immune defect that preceded recurrent orobuccal herpes disease.

After one month of taking the usual medication at an effective dosage, the teenagers received anti-VZV vaccination. Thereafter, no further recurrences occurred. The relationship between chickenpox and recurrent herpes disease was thus established in these two teenagers, suggested that treatment with anti-VZV vaccine might be beneficial for patients with recurrent orobuccal herpes disease.

The aim of the present study was to establish whether a possible correlation exists between the serological HSV1, HSV2, and VZV antibody levels and the observed clinical

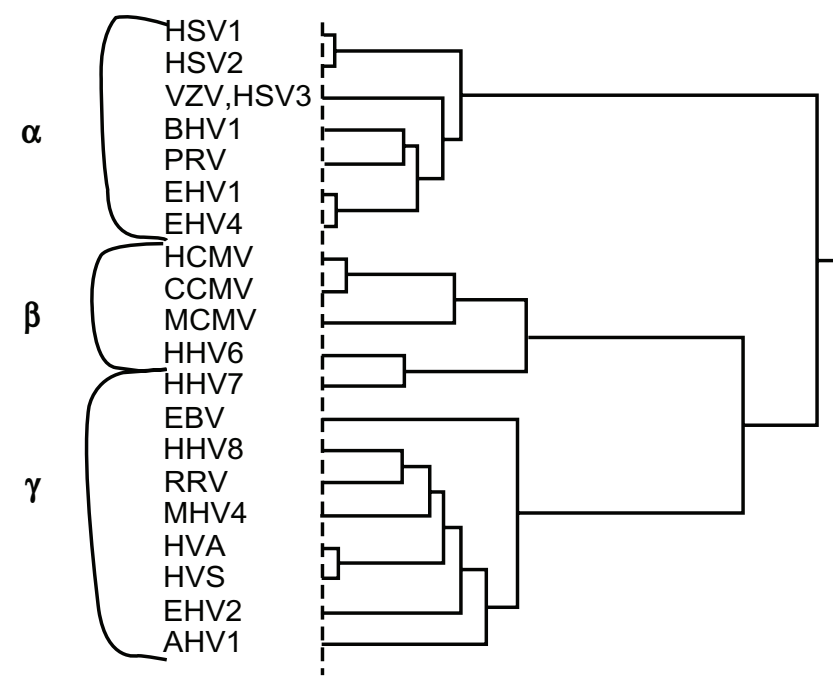

Figure I Phylogenetic tree of 20 members of the Herpesviridae family divided into three subfamilies, ie, Alphaherpesvirinae, Betaherpesvirinae, and Gammaherpesvirinae. Adapted from McGeoch et al.' results after anti-VZV vaccination. A suspected link between these orobuccal (HSV1) and genital (HSV2) herpes viruses and VZV might be revealed by the serological and clinical effects of the anti-VZV vaccine. Therefore, it was decided to follow up these interesting clinical observations in a larger number of herpes patients attending our medical practice.

\section{Materials and methods}

\section{Patient recruitment and inclusion criteria}

Since 2005, among 50 patients with common herpes simplex disease diagnosed in dermatological consultation, the conditions for inclusion of patients in the present study was to perform anti-VZV vaccination as a therapeutic alternative, instead of the continuous anti-herpes prophylaxis by usual chemotherapy. Of these patients, 24 otherwise healthy and immunocompetent adults had suffered from recurrent herpes over the preceding 2-6 years, with at least 6-8 herpes relapses per year (Tables 1 and 2).

\section{Primary and secondary outcomes}

The patients were informed of the trial therapeutic approach, which was based on genetic analysis of the herpes virus family tree. The very close genetic relationship that exists between HSV1, HSV2, and VZV was explained in detail to the patients, all of whom provided their informed consent to participate in the therapeutic vaccine study. The 50 patients were immunocompetent without symptoms of hypertension or diabetes that would require medical treatment affecting general immunity. This was controlled at the time of the first consultation of any patient. A glycemia level and blood count were obtained, as well as a human immunodeficiency virus test (necessarily negative for this study). Anti-HSV1, anti-HSV2, and anti-VZV antibody levels were measured as a control reference before any antiherpes treatment for all patients.

Administration of the anti-VZV vaccine as a possible therapy was proposed as a substitute for classical antiherpes therapy to the 50 herpes patients, 24 of whom agreed to participate in the trial. The anti-HSV1, anti-HSV2, and antiVZV antibody levels of the 26 nonvaccinated herpes patients served as reference controls for the 24 patients receiving the anti-VZV vaccine. One standard intradermal injection of anti-VZV vaccine was administered consistent with the dermatological requirement to stimulate skin cell-mediated immunity using the same anti-VZV vaccine (Oka Merck strain), being either $\operatorname{Varivax}^{\circledR}$ (sanofi-aventis, $0.5 \mathrm{~mL} /$ dose) or Varilrix ${ }^{\circledR}$ (GlaxoSmithKline, $0.5 \mathrm{~mL} /$ dose), as shown in Tables 3 and 4). 
Table I Recurrences of herpes in female patients before and after anti-VZV vaccination

\begin{tabular}{|c|c|c|c|c|c|c|c|}
\hline Patient & $\begin{array}{l}\text { Age } \\
\text { (years) }\end{array}$ & $\begin{array}{l}\text { Time of } \\
\text { consultation }\end{array}$ & $\begin{array}{l}\text { Recurrences } \\
\text { per year }\end{array}$ & Sites & $\begin{array}{l}\text { Long-term } \\
\text { therapy }\end{array}$ & $\begin{array}{l}\text { Anti-VZV } \\
\text { vaccine }\end{array}$ & $\begin{array}{l}\text { Recurrences } \\
\text { after anti-VZV } \\
\text { vaccine }\end{array}$ \\
\hline I & 57 & June 2006 & $>6$ & Orobuccal & Zovirax & 2 & 0 \\
\hline 2 & 37 & July 2008 & $>12$ & Orobuccal & Zelitrex & I & 0 \\
\hline 3 & 25 & February 2005 & $>8$ & Genital & Zovirax & 2 & 0 \\
\hline 4 & 47 & February 2005 & $>12$ & Genital & $\begin{array}{l}\text { Zovirax } \\
\text { Zelitrex }\end{array}$ & 2 & Fleeting I \\
\hline 5 & 68 & January 2008 & $>8$ & Genital & $\begin{array}{l}\text { Zovirax } \\
\text { Zelitrex }\end{array}$ & 3 & 0 \\
\hline 6 & 71 & March 2006 & $>10$ & Orobuccal & Zovirax & 2 & 0 \\
\hline 7 & 50 & February 2005 & $>8$ & Orobuccal & Zovirax & 4 & 0 \\
\hline 8 & 40 & June 2008 & $>6$ & Genital & Zelitrex & 2 & 0 \\
\hline 9 & 48 & $2006 / 02$ & $>8$ & $\begin{array}{l}\text { Orobuccal, } \\
\text { genital }\end{array}$ & $\begin{array}{l}\text { Zovirax, } \\
\text { Zelitrex }\end{array}$ & $1+1$ & 0 \\
\hline 10 & 33 & $2006 / 04$ & $>6$ & Orobuccal & Zovirax & 1 & Fleeting I \\
\hline II & 42 & April 2005 & $>8$ & Orobuccal & Zovirax & 1 & 0 \\
\hline 12 & 32 & March 2009 & $>10$ & Orobuccal & Valacyclovir & 1 & 0 \\
\hline 13 & 27 & April 2009 & $>8$ & Orobuccal & Valacyclovir & 1 & 0 \\
\hline 14 & 53 & February 2007 & $>8$ & $\begin{array}{l}\text { Orobuccal, } \\
\text { genital }\end{array}$ & Zovirax & 1 & 0 \\
\hline
\end{tabular}

After receiving the anti-VZV vaccine, the patients were requested to check their post-vaccination antibody levels. Of the treated and clinically cured patients $(n=24)$, only 12 agreed to have their HSV1, HSV2, and HSV3 antibody levels checked for 1-3 years after anti-VZV vaccination. The other vaccinated patients were still followed up by consultation and were cured and satisfied, but considered serological checks to be unnecessary $(\mathrm{n}=12)$.

Patient follow-up consisted of comparing the clinical criteria of effectiveness with serological antibody levels. This involved comparison of anti-HSV1, anti-HSV2, and anti-VZV antibody levels in nonvaccinated patients $(n=26)$ with those in vaccinated patients $(n=24)$. Only one biological variable was significant, ie, the rise in anti-VZV antibody, which correlated well with the clinical efficacy of the antiVZV vaccine against recurrent HSV1 and HSV2 herpes simplex disease.

\section{Medication and assignments}

Serological antibody titers were determined for each patient prior to conventional treatment for acute herpes infection using Zovirax (acyclovir) or Zelitrex (valacyclovir). Four to six weeks later, each patient received an intradermal antiVZV vaccination after undergoing standard therapy.

Table 2 Recurrences of herpes in male patients before and after anti-VZV vaccination

\begin{tabular}{|c|c|c|c|c|c|c|c|}
\hline Patient & $\begin{array}{l}\text { Age, } \\
\text { years }\end{array}$ & $\begin{array}{l}\text { Time of } \\
\text { consultation }\end{array}$ & $\begin{array}{l}\text { Recurrences } \\
\text { per year }\end{array}$ & Sites & $\begin{array}{l}\text { Long-term } \\
\text { therapy }\end{array}$ & $\begin{array}{l}\text { Anti-VZV } \\
\text { vaccine }\end{array}$ & $\begin{array}{l}\text { Recurrences } \\
\text { after anti-VZV } \\
\text { vaccine }\end{array}$ \\
\hline 15 & 59 & February 2008 & $4-6$ & $\begin{array}{l}\text { Orobuccal, } \\
\text { genital }\end{array}$ & Zelitrex & 2 & 0 \\
\hline 16 & 66 & February 2007 & $4-6$ & Orobuccal & Zelitrex & 2 & 0 \\
\hline 17 & 66 & April 2006 & $>6$ & Orobuccal & Zovirax & I & 0 \\
\hline 18 & 69 & September 2005 & $>6$ & Orobuccal & Zovirax & 2 & 0 \\
\hline 19 & 54 & February 2005 & $>6-10$ & Orobuccal & Zovirax & I & 0 \\
\hline 20 & 45 & March 2005 & $>6$ & Genital & Zovirax & 2 & 0 \\
\hline 21 & 56 & March 2006 & $>6$ & Genital & Zovirax & 2 & Fleeting I \\
\hline 22 & 26 & April 2009 & $>8$ & $\begin{array}{l}\text { Orobuccal, } \\
\text { genital }\end{array}$ & Zovirax & I & 0 \\
\hline 23 & 53 & January 2010 & $>8$ & $\begin{array}{l}\text { Orobuccal, } \\
\text { genital }\end{array}$ & Valacyclovir & I & 0 \\
\hline 24 & 55 & February 2009 & $>6$ & Orobuccal & Valacyclovir & I & 0 \\
\hline
\end{tabular}


Table 3 Comparison of HSVI, HSV2, and HSV3 antibody levels in the herpes control group $(n=26)$ and the recurrent herpes patient group $(n=24)$ before anti-VZV vaccination

\begin{tabular}{lccc}
\hline & $\begin{array}{l}\text { Ab levels in 26 controls } \\
\text { Mean (median) } \pm \text { SEM }\end{array}$ & $\begin{array}{l}\text { Ab levels in 24 patients with } \\
\text { recurrent herpes } \\
\text { Mean (median) } \pm \text { SEM }\end{array}$ & $P$ value \\
\hline Anti-HSVI Ab level & $3.38(0.9) \pm 1.029$ & $3.171(3.45) \pm 0.3101$ & 0.031 \\
Anti-HSV2 Ab level & $2.768(0.9) \pm 0.9173$ & $1.581(0.9) \pm 0.279$ & 0.1 \\
Anti-HSV3 Ab level & $0.69(0.7) \pm 0.069$ & $0.79(0.5) \pm 0.083$ & 0.4159 \\
\hline
\end{tabular}

Note: The statistical analysis was performed using the Wilcoxon rank-sum test, and the $P$ values are not significant.

Abbreviations: Ab, antibody; SEM, standard error of the mean; VZV, varicella zoster virus.

During this study, 24 patients (14 women, 10 men, mean age 51 [range 26-71] years) with recurrent herpes agreed to be vaccinated. Thirteen patients had orobuccal HSV1 herpes, six had genital HSV2, and five patients had orobuccal and genital herpes. Some patients were seropositive for both HSV1 and HSV2, even though recurrent herpes manifestations were limited to orobuccal herpes.

Factors that triggered relapses were identified in 20 cases, ie, menses in 12 women, and exposure to sun in eight men. All the women who participated in the study were on hormonal treatment for contraceptive reasons or as replacement therapy during menopause.

Following one anti-VZV vaccination, the mean annual number of herpes relapses decreased from 6-8 to zero. If requested by the patient, the anti-VZV vaccine was followed several months to one year later by a second injection, as recommended for children and proposed over ten years ago in the US. One dose of anti-VZV vaccine protected $76 \%$ of children, but $89 \%-99 \%$ were protected with two doses. The immune response is thus adequate with one dose. ${ }^{8,9}$

One year after the first vaccination, five women and five men who were clinically cured of recurrent herpes disease but feared relapses requested a second vaccination. One year after the first or second vaccination, a booster dose of anti-VZV vaccine was performed at the request of two clinically cured but very anxious female patients. The decision was made to comply with patient requests as long as vaccination was not harmful. Serological controls performed in these 12 patients after the first, second, or third injection showed that the level of anti-VZV antibody had greatly increased.

Clinical effectiveness was evaluated using the frequency of relapse at one, 2, and 5 years following vaccination, and by whether or not antiviral therapy was required. During this period, no herpes relapses were observed and no antiviral therapy was needed. Systematic serological measurements were performed in the 50 herpes patients in this study before any other treatment was given in order to be able to compare nonvaccinated herpes patients with those who were vaccinated with anti-VZV (Figure 2A and B).

\section{Serological controls}

Analyses of antibody levels prior to and after anti-VZV vaccination between 2005 and 2011 were determined by the Cerba and Biomnis laboratories, using the same enzyme-linked immunosorbent assay and electrochemoluminescence techniques. These laboratories use DiaSorin SpA kits to measure anti-HSV1, antiHSV2, and anti-VZV titers, have standardized data based on the results of Sauerbrei et al, ${ }^{10}$ and follow the interpolation of VZV assays based on standard curves, whereby a cutoff ratio of $0.9 / 1$ is correlated with $275 / 280 \mathrm{IU} / \mathrm{mL}$.

For a healthy individual free of herpes, the standard serological HSV1/HSV2 antibody ratio is $<0.9 / 1$. In all our 50 herpes patients, the anti-HSV1 and anti-HSV2 antibody levels were expressed as a ratio $>1$. A healthy herpes-free individual who has been exposed to chickenpox during childhood carries an anti-VZV antibody level expressed as

Table 4 Comparison of HSVI, HSV2 and HSV3 antibody levels in the herpes control group and the vaccinated herpes group after anti-VZV vaccination

\begin{tabular}{llll}
\hline & $\begin{array}{l}\text { Ab levels in nonvaccinated } \\
\text { herpes controls } \\
\text { Mean (median) } \pm \text { SEM }\end{array}$ & $\begin{array}{l}\text { Ab levels in I2 herpes patients } \\
\text { after vaccination } \\
\text { Mean (median) } \pm \text { SEM }\end{array}$ & $P$ value \\
\hline Anti-HSVI Ab level & $3.38(0.9) \pm 1.029$ & $2.67(2.8) \pm 0.491$ & 0.5073 \\
Anti-HSV2 Ab level & $2.77(0.9) \pm 0.917$ & $1.63(1.4) \pm 0.337$ & 0.9831 \\
Anti-HSV3 Ab level & $0.69(0.7) \pm 0.069$ & $1.69(1.4) \pm 0.211$ & $<0.000$ I \\
\hline
\end{tabular}

Notes: Statistical analysis was done using the Wilcoxon rank-sum test. The $P$ value was significant at $<0.00$ I.

Abbreviations: Ab, antibody; SEM, standard error of the mean; VZV, varicella zoster virus. 
A

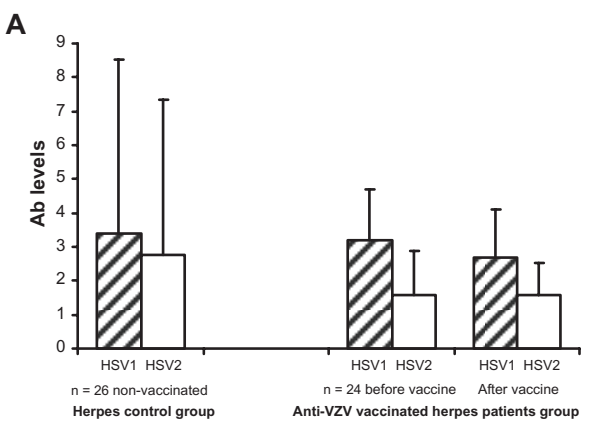

B

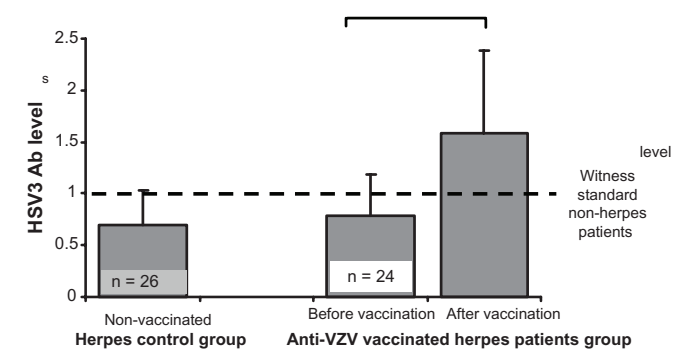

C

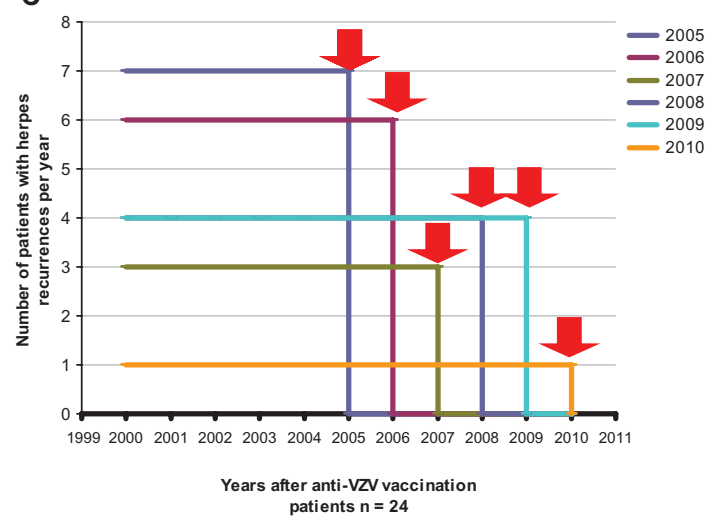

Figure 2 (A) Evolution of anti-HSVI and anti-HSV2 antibody levels in 24 patients with recurrent herpes before and after anti-VZV vaccination. The $P$ value is not statistically significant. Referring to Table 3 , the values are expressed as the mean \pm standard deviation and represent anti-HSVI and anti-HSV2 antibody levels of the nonvaccinated herpes control group and the vaccinated herpes group before and after herpes anti-VZV vaccine. (B) Evolution of anti-VZV antibody levels before and after anti-VZV vaccination in patients with recurrent herpes. $* * P<0.001$ is significant after anti-VZV vaccination (Wilcoxon's signed-rank test). Referring to Table 4, the values are expressed as the mean \pm standard deviation and represent normalized anti-VZV antibody levels in the non-vaccinated herpes control group and in antiVZV vaccinated patients before and after anti-VZV vaccination. (C) Efficiency of antiVZV vaccination showing that herpes recurrences (at least eight per year) for al 24 patients decreased to zero after anti-VZV vaccination (highlighted by red arrow). Abbreviation: VZV, varicella zoster virus.

a ratio $>4.5$ or $>1450 \mathrm{IU} / \mathrm{mL}$. Anti-VZV antibody levels were generally low for all our herpes patients, and expressed as a ratio $<4.5$ or $<1450 \mathrm{IU} / \mathrm{mL}$.

To compare anti-VZV antibody levels expressed either as a ratio or as $\mathrm{IU} / \mathrm{mL}$, all the data were normalized by dividing the anti-VZV antibody level by 4.5 when expressed as a ratio, and by 1450 when expressed as IU $/ \mathrm{mL}$. The serological sources of the data were the analyses of anti-HSV1,

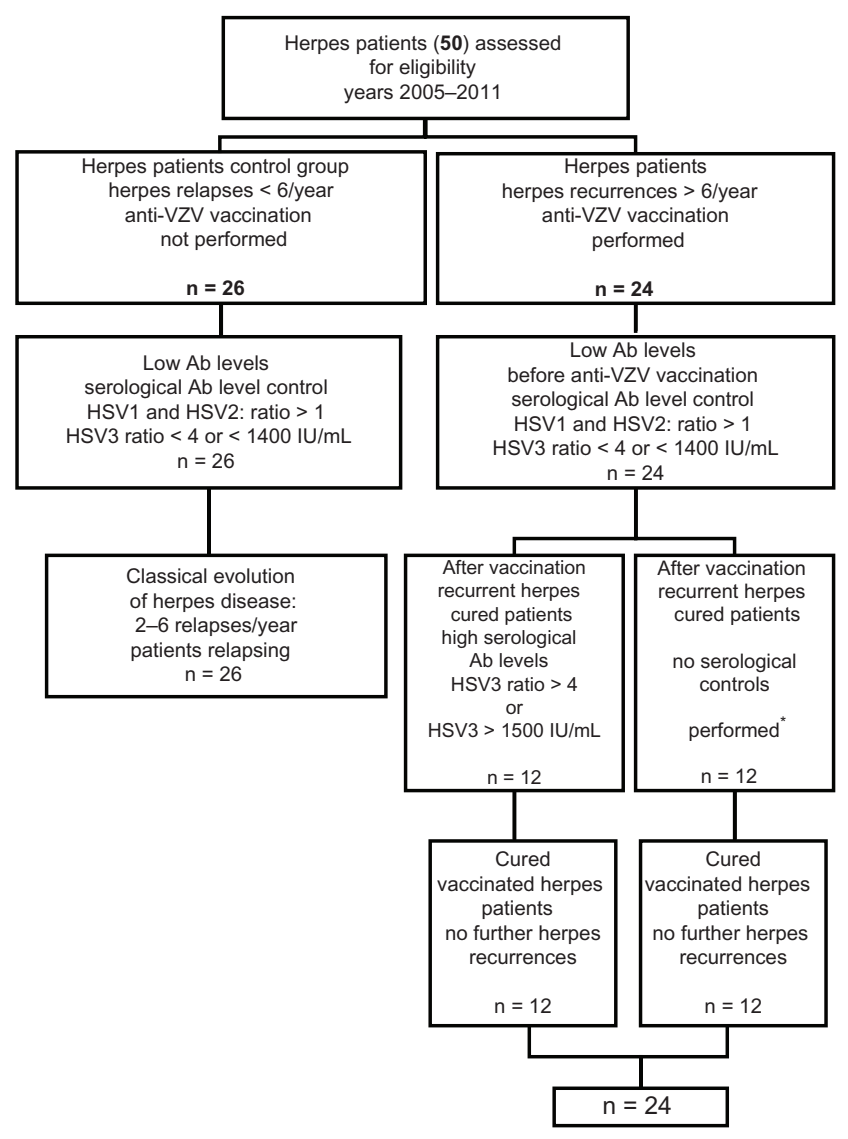

Figure 3 Flow chart for herpes patients at the time of analysis.

Note: *Twelve vaccinated patients who were clinically cured and satisfied refused to undergo further serological testing.

anti-HSV2, and anti-HSV3 antibody titers of the patients before and after anti-VZV vaccination.

\section{Results}

In this study, of the 24 vaccinated patients who were cured, 11 received only one subcutaneous vaccination and showed complete recovery from herpes disease, as did the 13 patients who received a second or third anti-VZV vaccination. These patients were all free of recurrences of herpes simplex several years later.

In the control group of 26 patients who did not receive the anti-VZV vaccine, classical evolution of herpes disease was observed, ie, 2-6 relapses per year. Among the 24 patients which received the anti-VZV herpes vaccination, the annual number of recurrences fell to zero after the initial vaccination (Figure 2C).

Clinical follow-up of the vaccinated patients was by consultation at specified times over several years. A few patients reported a fleeting or prickling sensation or redness lasting a few hours, but in no case did this warrant standard anti-herpes treatment. With regard to side effects, erythema or 
edema 4-5 cm in diameter that lasted 5-8 days (three cases) was detected at the injection site, but resolved spontaneously. Patients with recurrent herpes simplex disease typically require conventional antiviral treatment for an average of 150 days per year. After anti-VZV vaccination, this requirement decreased to zero (Tables 1 and 2, Figure 2C).

Before anti-VZV vaccination, the anti-VZV antibody titers of all the herpes patients $(n=50)$ was comparable, and the difference in the mean anti-VZV antibody level was not significant ( $P=0.416$, Wilcoxon's rank-sum test). After anti-VZV vaccination, the anti-VZV antibody titers of the 12 vaccinated patients who agreed to undergo further serological testing were significantly higher than the levels of the 26 nonvaccinated herpes patients $(P<0.001$, Wilcoxon's rank-sum test). Anti-VZV antibody levels (Figure 2A) were increased by two-fold compared with the levels before vaccination. This increase was significant $(P<0.001$, Wilcoxon's signed-rank test, Figure 2B). In healthy individuals, enhancement of anti-VZV antibody levels demonstrates the effectiveness of anti-VZV vaccination and its powerful role in protecting against herpes recurrences, although anti-HSV1 and anti-HSV2 antibody levels either remained stable or decreased slowly by a factor of 1.2 .

These positive clinical results provide remarkable preliminary evidence of the efficiency of the anti-VZV vaccine as a cure for recurrent herpes disease. Two patients in this study are now described in more detail with regard to the relationship between herpes simplex disease recurrence and serological anti-VZV antibody immune deficiency.

\section{Patient I}

For over ten years, this woman had suffered from recurrent genital HSV2 herpes resistant to low-dose acyclovir taken as ongoing conventional prophylaxis. She had neither the anti-HSV1 antibody nor the anti-HSV2 antibody, and had a very low level of anti-VZV antibody before receiving the anti-VZV vaccine. After anti-VZV vaccination, her HSV1 and HSV2 antibody levels increased slightly, but her anti-VZV antibody levels doubled, with no further herpes recurrences.

\section{Patient 2}

In 2006, a 65-year-old woman who had had herpes recurrences for many years received the anti-VZV vaccine, with no further relapses. In 2007, the patient successfully underwent surgery for abdominal cancer. This case is surprising because the patient would have had immune suppression for some time because of her underlying malignancy. Serological
anti-VZV antibody titers, measured in 2006, 2007, and 2011, were very low. These VZV serological defects would appear to be linked to her immune depression as a result of having cancer and, for this reason, this patient was not included in the results, but was cured of recurrent herpes disease. This observation highlights the potent cell-mediated immunity acquired through the anti-VZV vaccine which persisted in spite of the emergence of cancer.

\section{Discussion}

In this study, we evaluated the immunological status of HSV1 and HSV2, two members of the large family of herpes viruses, and they appeared to be related to VZV. Our therapeutic decision-making with respect to recurrent herpes was based on these observations. The genetic link between VZV and the other herpes viruses of the order Herpesvirales can be considered a primordial event with an outcome specific to the immunogenetic human leucocyte antigen. This relationship must be taken into account within the framework of the phylogenetic tree of the herpes viruses ${ }^{1}$ (Figure 1).

Herpesviridae comprises three subfamilies, ie, Alphaherpesvirinae, Betaherpesvirinae, and Gammaherpesvirinae. HSV1 and HSV2 are members of the Alphaherpesvirinae subfamily. They induce vesicles on the skin, and are most frequently expressed in the mouth or larynx and on the genital or rectal mucosa. However, they persist for months at the epidermal level surrounding the ends of peripheral nerves. Herpes viruses can also remain latent at the level of the nodes during the entire life of their host. ${ }^{4}$ Among the members of the Betaherpesvirinae, HSV5 (human cytomegalovirus) is linked to lymphoproliferative disease and congenital malformation. Members of the Gammaherpesvirinae include HSV4 (Epstein-Barr virus), responsible for lymphoma, including Hodgkin's lymphoma and HSV8, which is linked to Kaposi's sarcoma.

The first anti-VZV vaccine was the "Oka strain" varicella vaccine produced by Takahashi et al. ${ }^{11,12}$ This viral strain was isolated from typical vesicular varicella in an otherwise healthy child. The vaccine was used initially to prevent varicella in high-risk leukemic children. ${ }^{12}$ The children all remained free of varicella after anti-VZV vaccination. Thus, the tolerance and the safety of the vaccine is considered excellent. ${ }^{11,12}$

Since the end of 2004, the anti-VZV vaccine has been used in France to prevent chickenpox in children, and to prevent shingles in immune-depressed or older individuals. Prior to the present study, this anti-VZV vaccine had never been used to prevent recurrent herpes infection. Nevertheless, studies exist on the anti-VZV vaccine, and its potential 
pharmacodynamic properties has been speculated upon but not investigated. ${ }^{13}$ In spite of the limited number of patients involved in the present study and the absence of a comparative placebo/vaccine randomized trial, our results demonstrate the remarkable efficiency of the anti-VZV vaccine in 24 patients suffering from recurrent herpes simplex disease.

Human beings encounter the VZV more often during childhood than later in life. In all patients with recurrent herpes, anti-VZV antibody titers are present but their levels are low. The anti-VZV vaccine, originally approved for children, has been used throughout the world since the 1980s. It is effective, harmless, ${ }^{13}$ and well tolerated in immunocompetent children; however, the Oka VZV vaccine has been implicated in varicella in six immunocompromised patients. ${ }^{14}$

These findings warrant a second study involving a larger cohort with a control group in order to evaluate a possible placebo effect, although a report involving patients with HSV2 following classical herpes treatment with acyclovir or valacyclovir versus placebo showed no placebo effect. ${ }^{15}$ The well tolerated anti-VZV vaccine induced a high increase in serological anti-VZV antibodies in parallel with clinical cure in patients. Anti-HSV1 and anti-HSV2 antibody levels vary slightly, increasing, decreasing, or remaining stable after administration of the anti-VZV vaccine with nonsignificant $P$ values, and they may be considered residual "serological scars" of herpes disease.

The therapeutic effect of the anti-VZV vaccine on recurrent herpes disease might be attributed to a cell-mediated immune response, because T lymphocytes, CD8 cells, and natural killer cells are known to be involved in herpes. ${ }^{16}$ If this hypothesis is correct, it would suggest immunological induction of cellmediated cross-reactivity between HSV1, HSV2, and HSV3 due to specific VZV (HSV3) antigens. Subsequent polyclonal lymphocyte stimulation would then trigger the clinical anti-herpes efficiency observed here using the anti-VZV vaccine. ${ }^{17}$

In conclusion, the remarkable therapeutic effectiveness of the anti-VZV (anti-HSV3) vaccine in preventing recurrent herpes simplex disease due to HSV1 and HSV2 clearly demonstrates the efficacy of anti-VZV vaccination. In addition, our results suggest that cell-mediated cross-reactivity would be involved between HSV1, HSV2, and VZV, as demonstrated by the serological increase in anti-VZV antibody titers. A randomized trial with a larger cohort of patients has been initiated after this promising prospective study.

\section{Acknowledgments}

The authors thank Physiologie et Tumeur, an independent not-for-profit research institution in Paris, France, for its support. They are also grateful to Professor Jacques Benichou for statistical advice, Professor Camille Frances for her advice and constructive comments regarding this study, to Professor Allan Goldstein for his constructive comments and valuable suggestions regarding the manuscript, and to Professor Michiaki Takahashi, who originally created the Oka strain anti-varicella vaccine, for his enthusiasm, constant support, and encouragement to publish our research.

\section{Disclosure}

The authors report no conflicts of interest in this work.

\section{References}

1. McGeoch DJ, Dolan A, Ralph AC. Toward a comprehensive phylogeny for mammalian and avian herpes viruses. $J$ Virol. 2000;74:10401-10406.

2. Davison AJ, Eberle R, Ehlers B, et al. The order Herpesvirales. Arch Virol. 2009; 154:171-177.

3. McGeoch DJ, Rixon FJ, Davison AJ. Topics in herpesvirus genomics and evolution. Virus Res. 2006;117:90-104.

4. Favoreel HW. Immune evasion of alpha herpes viruses. Verh $\mathrm{K}$ Acad Geneeskd Belg. 2008;701:47-65. Dutch.

5. Giehl KA, Müller-Sander E, Rottenkolber M, Degitz K, Volkenandt M, Berking C. Identification and characterization of 20 immunocompetent patients with simultaneous varicella zoster and herpes simplex virus infection. J Eur Acad Dermatol Venereol. 2008;22:722-728.

6. Schmidt NJ, Lennette EH, Magoffin RL. Immunological relationship between herpes simplex and varicella-zoster viruses demonstrated by complement-fixation, neutralization and fluorescent antibody tests. J Gen Virol. 1969;4:321-328.

7. Sadaoka K, Okamoto S, Gomi Y, et al. Measurement of varicella-zoster virus (VZV)-specific cell-mediated immunity: comparison between VZV skin test and interferon-gamma enzyme-linked immunospot assay. J Infect Dis. 2008;198:1327-1333.

8. Gershon AA, Katz SL. Perspective on live varicella vaccine. J Infect Dis. 2008;197 Suppl 2:S242-S245.

9. Marin M, Meissner HC, Seward JF. Varicella prevention in the United States: a review of successes and challenges. Pediatrics. 2008;122:e744-e751.

10. Sauerbrei A, Färber I, Brandstädt A, Schacke M, Wutzler P. Immunofluorescence test for highly sensitive detection of varicellazoster-virus specific $\operatorname{IgG}$ - alternative to fluorescent antibody to membrane antigen test. J Virol Methods. 2004;119:25-30.

11. Takahashi M, Otsuka T, Okuno Y, Asano Y, Yazaki T, Isomura S. Live vaccine used to prevent the spread of varicella in children in hospitals. Lancet. 1974;2:1288-1290.

12. Takahashi M. Current status and prospects of live varicella vaccine. Vaccine. 1992;10:1007-1014.

13. Kockler DR, McCarthy MW. Zoster vaccines live. Pharmacotherapy. 2007;27:1013-1019.

14. Galea SA, Sweet A, Beninger P, et al. The safety profile of varicella vaccine: a 10-year review. $J$ Infect Dis. 2008;197 Suppl 2: S165-S169.

15. Fife KH, Warren TJ, Justus SE, Heitman CK. An international, randomized, double-blind, placebo-controlled, study of valacyclovir for the suppression of herpes simplex virus type 2 genital herpes in newly diagnosed patients. Sex Transm Dis. 2008;35:668-673.

16. Koelle DM, Corey L. Herpes simplex: insights on pathogenesis and possible vaccines. Annu Rev Med. 2008;59:381-395.

17. Ferenczy MW. Prophylactic vaccine strategies and the potential of therapeutic vaccines against herpes simplex virus. Curr Pharm Des. 2007;13:1975-1988. 


\section{Efficacy of the anti-VZV (anti-} HSV3) vaccine in the treatment of HSVI and HSV2 recurrent herpes simplex diseases:

\section{a prospective study}

Names of the drugs used

I. Chemotherapy of Herpes diseases antibiotics and generics:

1. Zovirax, generic: Acyclovir $200 \mathrm{mg} \times 6 \mathrm{p} /$ day $\times$ 6 days

2. Zelitrex, generic: Valacyclovir $500 \mathrm{mg} \times 2 \mathrm{p} /$ day $\times$ 5 days
II. Oka Strain Varicella Vaccine: one dose $0.5 \mathrm{~mL}$ : two Laboratories:

1. Varivax Sanofi Aventis Laboratory $0.5 \mathrm{~mL} /$ one dose Oka/Merck Strain

2. Varilrix Glaxo Smith Kline Laboratory $0.5 \mathrm{~mL} / \mathrm{one}$ dose

Oka/Merck Strain

\section{Publish your work in this journal}

The Open Access Journal of Clinical Trials is an international, peerreviewed, open access journal publishing original research, reports, editorials, reviews and commentaries on all aspects of clinical trial design, management, legal, ethical and regulatory issues, case record form design, data collection, quality assurance and data auditing

methodologies. The manuscript management system is completely online and includes a very quick and fair peer-review system, which is all easy to use. Visit http://www.dovepress.com/testimonials.php to read real quotes from published authors. 